\title{
Professor GEORGE A. GIBSON, M.A., LL.D., F.R.s.E.
}

\author{
By Professor R. J. T. BeLL.
}

George Alexander Gibson was born at Greenlaw, Berwickshire, in 1858. His father was a man of rare capacity and character who wrote a history of Greenlaw and taught himself Latin so as to be able to obtain the material for his history from original documents.

After attending an elementary school at Greenlaw, Gibson enrolled in 1874 as a student at the University of Glasgow, where he gained the highest places in all the classes of the Arts curriculum. At this period of his life his health was not robust and it threatened to terminate his university studies. Consequently, in 1881, he took the degree of M.A. without honours. In the following year he was able to sit the honours examination in Mathematics and Natural Philosophy, and he so distinguished himself that he was awarded the Ewing Fellowship. When the degree of D.Sc. was afterwards insti. tuted and the regulation required that a candidate for it should have an honours degree in Arts or Science, his ordinary degree precluded Gibson from becoming a candidate for the doctorate which his published work would doubtless have gained for him.

He became Junior Assistant to Professor Jack in 1883 and Senior Assistant in the following year, and retained that position for eleven years. In 1889 he narrowly escaped going to New Zealand. He was a candidate for the Chair of Mathematics in the University of Otago and was, out of 54 applicants, commended by the Conmissioners in London to the Council in Otago as an exceptionally suitable candidate. The Council, however, in order to save the travelling allowance, appointed an applicant who was resident in New Zealand. Gibson used to say he felt this to be the biggest disappointment of his career.

When he began his teaching work in the University, the Assistants to the Professor were appointed and paid by the Professor himself, a system which was unsatisfactory in many ways. Gibson was a prominent member of the Committee of Assistants which prepared a statement for, and gave evidence before, the Universities' Commission of 1889. They emphasised the need for the creation 
of a new class of University teacher to meet the growing demands for instruction; and their representations led to the promotion of an Ordinance which empowered University Courts to appoint Lecturers.

Gibson regarded the six months' vacation of those times as a unique opportunity for mathematical study; to enable honours students to take due advantage of it, he organised and conducted tutorial classes. Here the students came into close personal contact with him and were invariably impressed by the great range of his knowledge, his enthusiasm for his subject, and his constant readiness to help.

The notification of his appointment, towards the end of 1895, as Professor in the Glasgow and West of Scotland Technical College, came to him as a telegram handed in by the janitor whilst he was lecturing. The students were aware of his candidature, and, inferring from his expression its successful outcome, expressed their congratulations in the usual fashion. He thanked them and stated that, whilst he was not ignorant of the drawbacks of his new post in the immaturity of the students and the large amount of evening work, he recognised its opportunities.

Of these opportunities Professor Gibson characteristically took full advantage. He increased the reputation as a teacher and administrator which he had made at the University. The number of students attending his classes grew and the standard of work was raised. The courses of study offered by the College were increased in number and scope; and as Chairman of the Board of Studies for several years, Gibson had an important influence on these developments. The effect of his contact with students whose main interest lay in the applications of Mathematics is seen in his Treatise on the Calculus, published in 1901. The examples in that work are largely drawn from physical and mechanical sources. In that respect the author returned to the practice of the earliest writers on the subject. The book is a monument to his skill and thoroughness as a teacher ; it has attained an international reputation and exerted a widespread influence in the teaching and presentation of the subject.

In 1909 Gibson returned to the University as successor to Professor Jack. The staff of the Mathematical Department was largely increased and, under his direction, large classes were subdivided and systematic tutorial instruction introduced. The elements of the Calculus and Analytical Geometry were included in the syllabus of 
work for the pass degree; the curriculum for honours was broadened and the standard raised, each student being required to read some branch of the subject not treated in the class lectures and to profess it for examination. The courses for engineering students were also reorganised.

The war years threw a great strain on Professor Gibson and the enlarged classes that followed them brought an addition to, rather than a relief from, the burden. His health had begun to fail, yet he insisted on taking his full share in the varied teaching work of the department, and meeting the heavy claims on his time and energy that his administrative work entailed. He was most reluctant to surrender any part of his duties if such surrender added to the work of any member of his staff, whilst he insisted on taking his share of any additional work that might arise.

Gibson gave valuable service to the University as a member, for a period, of the Court, and carried out other important administrative work on the Glasgow Provincial Committee for the Training of Teachers and on the Board of Governors of the Royal Technical College. Every question submitted to him was fully considered in the light of all the information he could obtain, and in all its bearings, before he came to a decision. His characteristic thoroughness, combined with the sanity of his judgment and his honesty and sincerity, gave him a great influence amongst his colleagues on administrative bodies.

In Gibson the Edinburgh Mathematical Society had a most enthusiastic supporter. He recognised the great infuence that the Society exerted on the mathematical teaching in Scotland, and was eager to extend and intensify that influence. His contributions to the publications of the Society cover a wide range of topics, and his papers on historical subjects, on which he was an authority, are of special interest and importance. In recognition of his services to the Society he was made an honorary member in 1902.

In 1927, Gibson's health brought about his retirement from his chair. Public recognition of his great services to education was made by the endowment, in the University of Glasgow, of a lectureship on the History of Mathematics. Until his death, on 1st April 1930, he was busily engaged in the preparation of a book on Advanced Calculus. This work, which he had just completed, embodies the results of his long study and wide experience as a teacher. It is bound to be one of special importance; and it is to be regretted that he did not live to see its publication. 